\title{
Causes of Culling and Disease Incidences At First Production Year of Imported Brown Swiss and Simmental Cows From Austria
}

\author{
Zeynep KUCUK BAYKAN'1, Mustafa OZCAN2*
}

${ }^{1}$ Republic of Turkey, Ministry of Agriculture and Forestry, Sarubanl District Agriculture Directorate, Manisa, 45800, Turkey 2Istanbul University-Cerrahpaşa, Veterinary Faculty, Department of Animal Breeding and Husbandry, Istanbul, 34320, Turkey

\begin{abstract}
The purpose of this study is to determine the disease incidences and the causes of culling of Brown Swiss and Simmental cows before and after calving. The study material was consisted of 70 Brown Swiss and 282 Simmental pregnant heifers. $8.57 \%$ and $9.57 \%$ of Brown Swiss and Simmental cows had various diseases before calving, and the treatment success rates were $16.67 \%$ and $81.48 \%$. After calving, the disease incidences of Brown Swiss cows was $75.39 \%$, and the disease incidences of Simmental cows was $64.26 \%$. While digestion and Genital diseases were more common before calving, Genital and udder problems were more common after calving. Simmental cows had a higher rate of treatment success before calving $(\mathrm{P}<0.05)$. Both breeds had similar rates of treatment success after calving. $7.14 \%$ of Brown Swiss cows were culled before calving, and $23.08 \%$ were culled after calving due to various reasons. For Simmental cows, the culling rate was $1.77 \%$ before calving and $14.08 \%$ after calving. Simmental cows were more disease-resistant, responded more positively to treatment and had a lower culling rate than Brown Swiss cows.
\end{abstract}

Keywords: Simmental, Brown Swiss, Disease, Culling, Adaptation

\section{Avusturya'dan İthal Edilen İsviçre Esmeri ve Simmental İneklerin İlk Üretim Yllındaki Hastalık İnsidensleri ve Ayıklama Sebepleri}

ÖZ

Çalışmanın amacı, İsviçre Esmeri ve Simmental ırkı gebe düvelerin buzağılama öncesi ve sonrası dönemde karşılaştıkları hastalıkların insidenslerini ve ineklerin sürü dışı edilme sebeplerini belirlemektir. Araştırmanın materyalini Avusturya'nın Innsbruck bölgesinden Türkiye'nin batısında bulunan Manisa iline getirilen 70 baş İsviçre Esmeri ve 282 baş Simmental ırklarından inekler oluşmuştur. İsviçre Esmeri ve Simmental inekler doğum öncesinde $\% 8,57$ ve $\% 9,57$ oranlarında değişik hastalıklar ile karşılaşmışlar, $\% 16,67$ ve $\% 81,48$ oranlarında tedavi başarısı elde edilmiştir. Buzağılama sonrası dönemde İsviçre Esmerlerinin hastalanma oran1 \%75,39 olurken, Simmental ineklerin oranı \%64,26 olarak tespit edilmiştir. Sindirim ve genital sistem problemleri buzağılama öncesinde, genital sistem ve meme problemleri buzağılama sonrasında daha yoğun olarak ortaya çıkmıştır. Buzağılama öncesi dönemde Simmental ineklerin tedavi başarısı daha yüksek olurken $(\mathrm{P}<0,05)$, buzağılama sonrasında her iki ırktan ineklerin tedavi başarı oranları birbirine yakın bulunmuştur. İsviçre Esmeri ineklerin \% 7,14’ü buzağılama öncesinde, \%23,08'i buzağılama sonrasında değişik sebeplere bağlı olarak sürü dış1 edilmiştir. Simmentallerde ayıklama oranı buzağılama öncesinde \%1,77 ve buzağılama sonrasinda $\% 14,08$ olarak tespit edilmiştir. Genel olarak, Simmental ineklerin hastalıklara karşı daha dirençli olmuşlar, uygulanan tedaviye daha yüksek oranda pozitif yanıt vermişler ve daha az oranda ayıklamaya tabi tutulmuşlardır.

Anahtar Kelimeler: Sığır, Simmental, İsviçre Esmeri, Hastalık, Adaptasyon

To cite this article: Kü̈ü̈k Baykan Z. Özcan M. Causes of Culling and Disease Incidences At First Production Year of Imported Brown Swiss and Simmental Cows From Austria. Kocatepe Vet J. (2019) 12(2):178-184. 


\section{INTRODUCTION}

In cattle enterprises, sustaining productivity in the following years depends on improving cattle's genetic capacity, and also optimizing the enterprise's environmental conditions, completing the cattle's adaptation to geographical, climatic and vegetative environment in a short period of time. It is reported that animals that are moved regionally or imported from abroad suffer from stress factors, and the negative conditions in terms of animal welfare and stress depress animal's immune system, increase disease incidence and prevalence and result in decreased productivity (Broom 2005).

The incidence of various health problems and treatment failures in dairy cattle cause extended periods of open days, delayed gestation, and extended periods between two calving. Those disorders in estrous cycle might lead to extended lactation periods in cows and decreases in lifetime milk yield and economic losses.

Various diseases affecting animals might also affect each other or trigger one another. A study found that there was a positive relation between cows' Genital insufficiencies and clinical mastitis cases, and since foot and leg problems prevent the visibility of heat symptoms, they postpone the insemination time and thus gestation (Maizon et al. 2004).

In dairy cattle enterprises, the disease incidences for per production year are considered as normal $2 \%$ for clinic mastitis per month and $<3 \%$ for retentio secondinarium, $5-25 \%$ for metritis, $<10 \%$ for cystic ovarian, $<3 \%$ for abomasum displacement and $<25 \%$ for lameness per year (Dinç 2016). One of the most important indicators of whether the herd management programs are successful in dairy cattle enterprises is the level of annual culling rates and the frequency of culling reasons. It is reported that the culling rate of enterprises per year is around $21-36 \%$ (Maher et al. 2008; Pinedo et al. 2010; Stojic et al. 2013), and while $12-18 \%$ is considered normal in terms of indicating heard health, this rate might reach $25 \%$ with the addition of voluntary culling (Dinç 2016).

The culling rates in herds change depending on the breed differences, disease incidences and frequency in herd, cows' age, lactation order, Genital and lactation performance and unexpected economic situations of enterprise. While Genital diseases are the most common causes of culling for cows in the herds, they are followed by mastitis, foot and hoof diseases and metabolism diseases respectively (Seegers et al. 1998, Fetrow et al. 2006, Pinedo et al. 2010, Stojic et al. 2013).
The study made by Pinedo et al. (2010) on 2054 Holstein herds found that the culling and mortality rates per year were $25.1 \%$ and $6.6 \%$ respectively. It reported that $20.6 \%$ of all of culling reasons were atypical deaths; this was followed by Genital problems (17.7\%), injuries (14.3\%) and low productivity and mastitis (12.1\%). In this research, among all culled and dead cows; the culling rate of young cows at their first calving year was $20 \%$. Stojic et al. (2013) found that, in herds with high yield, $32.5 \%$ of young cows that calved for the first time were culled for foot and hoof diseases, $19.9 \%$ were culled for Genital problems, and 11\% were culled for metabolic diseases. They reported that the culling rate due to Genital problems were lower in herds with low milk yield than high productive herds.

The aim of this study is to determine the disease incidences and treatment success rates of pregnant Simmental and Brown Swiss cows, which were imported from Austria to a private breeding dairy cattle enterprise in Manisa, before and after calving, to identify the culling reasons at the first production year. According to diseases and treatment incidences and culling rates of Simmental and Brown Swiss cows, it is possible to make scientific comments about importation success and adaptation ability in the West Anatolia location and compare between Simmental and Brown Swiss breeds at their first production year.

\section{MATERIAL and METHODS}

\section{Material Definition}

The study was conducted in a private dairy cattle enterprise, which was located in Manisa and which has recently started livestock operations. Manisa is located in Western Anatolia Region between 27 08' and $2905^{\prime}$ eastern longitudes and $380^{\prime \prime}$ and 39 58' northern latitudes. It has Mediterranean continental climate. Precipitation generally occurs in winter, and summer is dry. The temperature is below zero for an average of 26 days per year (Municipality of Manisa 2017).

The first animal materials of the enterprise were contained 352 pregnant, disease free (such as tuberculosis, blue tongue, bovine spongiform encephalopathy, foot and mouth disease) heifers imported from Innsbruck/Austria. Also their body weights were between $400 \mathrm{~kg}$ and $550 \mathrm{~kg}$. Of those cows, 70 were Brown Swiss and 282 were Simmental. The pregnant cows calved in the enterprise between June and December.

\section{Material Care and Feeding}

The cattle barns were constructed in a free range and semi-open system. When the cows were transported to the enterprise, they were first taken into quarantine, and then were placed in paddocks. The 
cows were vaccinated with IBR, BVD, Clostridium, Pasteurella vaccines and feed to special feeding with forage (Net energy maintenance-NEm:1,37 Mcal $/ \mathrm{kg}$, NEg:0,8 Mcal $/ \mathrm{kg}$, CP: 12,5\%DM, ADF: 31,4\%DM, NDF: $48,9 \% \mathrm{DM}$ ) at this period.

The cows which were lactation period had three different rations, namely fresh ration, lactation and dry-period rations. After calving, cows were subjected to post-calving feeding for 3 weeks, and then lactation feeding. First period ration, nutrient information was NEL (Net energy lactation): 1,62 $\mathrm{Mcal} / \mathrm{kg}, \mathrm{CP}$ (crude protein): 17,2\%DM (dry matter), ADF (acid detergent fiber): 20,22\%DM, NDF (neutral detergent fiber): $34,68 \% \mathrm{DM}$, starch: $24,4 \% \mathrm{DM}$. The ration consisted of: $14 \%$ alfalfa, $48 \%$ corn silage, $3 \%$ oat-barley hay, $11 \%$ seasonal pulp, $24 \%$ factory lactation feed mix. In the lactation period, NEL: 1,61 Mcal/kg, CP: 16,89\% DM, ADF: 22,67 \% DM, NDF: 37,33\% DM, starch: $23 \%$ DM and $11 \%$ alfalfa, $50 \%$ corn silage, $4 \%$ oat-barley hay, $12 \%$ seasonal pulp, $23 \%$ factory lactation feed mix was given. Lactation feed was prepared according to the cows with high and low milk yields in the progressing milking periods. The dry-period feed consisted of: $19 \%$ alfalfa, 38\% corn silage, $30 \%$ oatbarley hay, 4\% seasonal pulp, 9\% dry-period factory feed mix and NEL: 1,3 Mcal $/ \mathrm{kg}$, CP: 14,5\%DM, ADF: $31 \% \mathrm{DM}, \mathrm{NDF}: 49 \% \mathrm{DM}$, anion cation balance: $21,34, \mathrm{Ca} / \mathrm{P}: 1,9$.

\section{Disease Incidences}

The diseases detected in 352 cows (70 Brown Swiss, 282 Simmental) were divided into two as before calving (after transport) and after calving. The period after transport covered the period between the day when the cows were brought to the enterprise and the first calving; the period after calving covered the period between the $1^{\text {st }}$ calving and $2^{\text {nd }}$ one. The incidence and treatment success of diseases detected in those two periods were expressed proportionately. The culling and mortality causes of cows at the first production year were assessed according to breeds and diseases.

All cows were observed in point of behavior differences, body conditions and disease symptoms every day. The diseases were diagnosed by the enterprise's veterinarian by using the cow's body temperature, auscultation, palpation, urine and feces examination, various observation data, blood samples and ultrasound data.

The disease definitions were as follows:

A. Digestive problems: Ketosis, abomasum displacement, diarrhea, tympany and constipation;

B. Respiratory problems: Pneumonia cases presenting with mucous or sera-mucous nasal flow and , abdominal panting;
C. Genital Diseases: Uterine prolapsed, metritis, ovarian cysts, dystocia, chronic infertility cases;

D. Foot problem: Lameness or being unable to stand on a foot condition in one foot or more, swelling in joints, bleeding, fractures or cracks in extremities;

E. Udder problems: Traumatic udder injuries, udder edema, udder blindness and acute or chronic mastitis cases;

F. Other disorders: Cachexia, ketosis, idiopathic/atypical cases that occur due to the mistakes (contraindication after wrong treatment protocols, unexpected secondary infections, shortterm care and feeding mistakes, late observation of health problems etc.) of veterinarian, technician or caregiver or unknown reasons.

\section{Statistical analysis}

When calculating the disease incidences of cows, subgroups were made such as before calving, after calving, disease incidence, treatment success and mortality cause; the conditions of cases were addressed; and the results were presented by using values expressed in percentages. "Pearson Chi-Square Test" and "Fisher's Exact Test" were used for comparisons between groups. SPSS (Statistical Package for the Social Sciences) program package was used for all statistical analysis (SPSS 1999).

\section{RESULTS}

The disease incidences of Brown Swiss and Simmental cows were addressed separately for the before calving (after transport) and after calving periods.

The diseases in the period before calving covered the diseases that the pregnant cows had since their arrival in the enterprise until their first calving or abort, and these are shown in Table 1 . The detailed results of diseases are shown in Table 2. In the after transport/before calving period, $8.57 \%$ of Brown Swiss and $9.57 \%$ of Simmental cows were diagnosed various diseases. While there was no statistically significant difference between Brown Swiss and Simmental cows in terms of disease incidence, the positive response of sick cows to treatment was higher in Simmental cows (81.48\%) and this was statistically significant $(\mathrm{P}<0,05)$. The overall treatment success rate was $16.67 \%$ for Brown Swiss.

In the period before calving, the cows had cases of diarrhea, constipation, pneumonia, lameness. In this period, the treatment of diseases such as cachexia, lameness, diarrhea, constipation and pneumonia had a success rate between $75 \%$ and $100 \%$. It was seen that 12 cows, which were imported to the enterprise, were not pregnant or had early abort, and the cows were taken into treatment and re-insemination process. For the treatment of idiopathic infertility problems with unknown origins, treatment success rate was $71.43 \%$ for Simmental cows $(\mathrm{P}<0.05)$. However, the 
treatments for Brown Swiss failed, and the cows were culled.

After calving, diseases of various origins were detected in $75.39 \%$ of Brown Swiss and $64.26 \%$ of Simmental cows. According to the disease incidence and treatment success rates of Brown Swiss and Simmental cows between their $1^{\text {st }}$ and $2^{\text {nd }}$ calving, the distribution of other diseases (except for other disorders) was statistically insignificant according to breed. While digestive and respiratory system diseases were more common in Simmental cows, Genital diseases, foot diseases and udder diseases were more common in Brown Swiss. However, the differences between breeds were statistically insignificant ( $\mathrm{P}>0.05)$.

After calving, the most common cases were metritis, ovarian cysts, mastitis and cachexia. The rate of cachexia was $13.85 \%$ in Brown Swiss and 3.25\% in Simmental, which was statistically significant $(\mathrm{P}<0.05)$. When treatment success rates were evaluated in general, uterine prolapse and uterus abscess cases had the lowest treatment success. Higher treatment success was obtained in treating metritis in Simmental cows $(\mathrm{P}<0.05)$.

Table 3 indicates the causes of cow mortality and culling before and after calving in the first production year. 10 cows died or were culled before calving, and 54 cows died or were culled after calving due to various reasons. Brown Swiss had more losses before and after calving. Before calving, Brown Swiss cows died or were culled only due to idiopathic infertility, while Simmental cows died or were culled due to diarrhea, constipation, pneumonia, lameness and idiopathic infertility etc. After calving, retentio secondinarium was the only condition that did not cause mortality/culling. For Brown Swiss, mortality/culling due to cachexia had a higher rate compared to Simmental $(\mathrm{P}<0.05)$. Cachexia is including anorexia in this research. It is looking as a consequence of the loss of appetite metabolic disorders in dairy farm. In postpartum period, some cows have shown anorexia and debility due to difficult birth. This status can cause the cows to weaken over time.

\section{DISCUSSION and CONCLUSION}

The imported Brown Swiss and Simmental cows had a disease ratio of $9.38 \%$ before calving, and the treatment success rate was $70 \%$. Before calving, Simmental mostly had digestive problems, and Brown Swiss had genital diseases. Simmental cows had a higher treatment success rate in this period. This can be explained by the less group number of Brown Swiss cows in the enterprise and to be more resistant of Simmental cows to changing environmental conditions and transportation.

The most common diseases encountered by both breeds after $1^{\text {st }}$ calving were: Genital diseases $(33.33 \%)$, udder diseases $(12.86 \%)$, digestive system problem (5.55\%), foot diseases (5.26\%), and respiratory system problem $(4.09 \%)$ respectively. These results were consistent with the findings in literature, which reports that Genital and udder diseases were more common in dairy cattle enterprises (Seegers et al. 1998, Fetrow et al. 2006, Pinedo et al. 2010, Stojic et al. 2013). According to the incidence of specific diseases; the incidence of metritis $(13.16 \%)$, mastitis $(9.06 \%)$, ovarian cyst $(8.18 \%)$, and retentio secondinarium $(4.09 \%)$ were higher than other diseases.

The annual rates were considered normal for diseases in breeding dairy cattle enterprises are: $<3 \%$ for retentio secondinarium, $5-25 \%$ for metritis, $<10 \%$ ovarian cysts, $2 \%$ for clinic mastitis, $<3 \%$ for abomasum displacement, $<25 \%$ for lameness, and $<35 \%$ for culling (Dinç 2016). Accordingly, while the incidences of metritis and ovarian cysts were reasonable in the enterprise, the incidences of mastitis and retentio secondinarium were above normal.

Table 1. Incidence and treatment success of system diseases in Brown Swiss and Simmental cows before and after calving $(\%)$

\begin{tabular}{|c|c|c|c|c|c|c|c|c|c|c|c|c|c|c|c|c|}
\hline \multirow{4}{*}{ DISEASES } & \multicolumn{8}{|c|}{ BEFORE CALVING } & \multicolumn{8}{|c|}{ AFTER CALVING } \\
\hline & \multicolumn{4}{|c|}{ INCIDENCE } & \multicolumn{4}{|c|}{ TREATMENT SUCCESS } & \multicolumn{4}{|c|}{ INCIDENCE } & \multicolumn{4}{|c|}{ TREATMENT SUCCESS } \\
\hline & \multicolumn{2}{|c|}{$\begin{array}{c}\text { Brown Swiss } \\
(\mathrm{N}: 70)\end{array}$} & \multicolumn{2}{|c|}{$\begin{array}{l}\text { Simmental } \\
(\mathrm{N}: 282)\end{array}$} & \multicolumn{2}{|c|}{$\begin{array}{c}\text { Brown Swiss } \\
(\mathrm{N}: 70)\end{array}$} & \multicolumn{2}{|c|}{$\begin{array}{l}\text { Simmental } \\
(\mathrm{N}: 282)\end{array}$} & \multicolumn{2}{|c|}{$\begin{array}{c}\text { Brown Swiss } \\
\text { (N:65) }\end{array}$} & \multicolumn{2}{|c|}{$\begin{array}{c}\text { Simmental } \\
(\mathrm{N}: 277)\end{array}$} & \multicolumn{2}{|c|}{$\begin{array}{c}\text { Brown Swiss } \\
\text { (N:65) }\end{array}$} & \multicolumn{2}{|c|}{$\begin{array}{l}\text { Simmental } \\
(\mathrm{N}: 277)\end{array}$} \\
\hline & $\mathbf{n}$ & $\%$ & $\mathbf{n}$ & $\%$ & $\mathbf{n}$ & $\%$ & $\mathrm{n}$ & $\%$ & $\mathbf{n}$ & $\%$ & $\mathbf{n}$ & $\%$ & $\mathbf{n}$ & $\%$ & $\mathbf{n}$ & $\%$ \\
\hline Digestive system diseases & 0 & 0 & 14 & 4.96 & 0 & 0 & 13 & 92.86 & 1 & 1.54 & 18 & 6.50 & 1 & 100.00 & 17 & 94.44 \\
\hline Respiratory system diseases & 1 & 1.43 & 4 & 1.42 & 1 & 100.00 & 3 & 75.00 & 1 & 1.54 & 13 & 4.69 & 1 & 100.00 & 9 & 69.23 \\
\hline Genital system diseases & 5 & 7.14 & 7 & 2.48 & 0 & $0.00^{\mathrm{b}}$ & 5 & $71.43^{\mathrm{a}}$ & 25 & 38.46 & 89 & 32.13 & 18 & 72.00 & 72 & 80.89 \\
\hline Foot diseases & 0 & 0 & 1 & 0.35 & 0 & 0 & 1 & 100.00 & 4 & 6.15 & 14 & 5.02 & 4 & 100.00 & 9 & 64.29 \\
\hline Udder diseases & 0 & 0 & 0 & 0 & 0 & 0 & 0 & 0 & 9 & 13.85 & 35 & 12.64 & 6 & 66.67 & 24 & 68.57 \\
\hline Other disorders & 0 & 0 & 1 & 0.35 & 0 & 0 & 0 & 0 & 9 & $13.85^{\mathrm{a}}$ & 9 & $3.25^{b}$ & 5 & 55.56 & 8 & 88.89 \\
\hline GENERAL & 6 & 8.57 & 27 & 9.57 & 1 & $16.67^{b}$ & 22 & $81.48^{\mathrm{a}}$ & 49 & 75.39 & 178 & 64.26 & 35 & 71.43 & 139 & 78.09 \\
\hline
\end{tabular}

a, $\mathbf{b}$ : Differences between the rates with different letters in the same lines are significant $(\mathrm{P}<0,05)$. 
Table 2. Incidence and treatment success of specific diseases in Brown Swiss and Simmental cows before and after calving $(\%)$

$$
\text { BEFORE CALVING }
$$

AFTER CALVING

\begin{tabular}{|c|c|c|c|c|c|c|c|c|c|c|c|c|c|c|c|}
\hline \multicolumn{4}{|c|}{ INCIDENCE } & \multicolumn{4}{|c|}{ TREATMENT SUCCESS } & \multicolumn{4}{|c|}{ INCIDENCE } & \multicolumn{4}{|c|}{ TREATMENT SUCCESS } \\
\hline \multicolumn{2}{|c|}{$\begin{array}{c}\text { Brown Swiss } \\
(\mathrm{N}: 70)\end{array}$} & \multicolumn{2}{|c|}{$\begin{array}{c}\text { Simmental } \\
(\mathrm{N}: 282)\end{array}$} & \multicolumn{2}{|c|}{$\begin{array}{c}\text { Brown Swiss } \\
\text { (N:70) }\end{array}$} & \multicolumn{2}{|c|}{$\begin{array}{c}\text { Simmental } \\
(\mathrm{N}: 282)\end{array}$} & \multicolumn{2}{|c|}{$\begin{array}{c}\text { Brown Swiss } \\
\text { (N:65) }\end{array}$} & \multicolumn{2}{|c|}{$\begin{array}{c}\text { Simmental } \\
(\mathrm{N}: 277)\end{array}$} & \multicolumn{2}{|c|}{$\begin{array}{c}\text { Brown Swiss } \\
\text { (N:65) }\end{array}$} & \multicolumn{2}{|c|}{$\begin{array}{c}\text { Simmental } \\
(\mathrm{N}: 279)\end{array}$} \\
\hline $\mathrm{n}$ & $\%$ & $\mathrm{n}$ & $\%$ & $\mathrm{n}$ & $\%$ & $\mathrm{n}$ & $\%$ & $\mathrm{n}$ & $\%$ & $\mathrm{n}$ & $\%$ & $\mathrm{n}$ & $\%$ & $\mathrm{n}$ & $\%$ \\
\hline 0 & 0 & 0 & 0 & 0 & 0 & 0 & 0 & 0 & 0 & 7 & 2.53 & 0 & 0 & 7 & 100.00 \\
\hline 0 & 0 & 0 & 0 & 0 & 0 & 0 & 0 & 0 & 0 & 2 & 0.72 & 0 & 0 & 2 & 100.00 \\
\hline 0 & 0 & 14 & 4.96 & 0 & 0 & 13 & 92.86 & 1 & 1.54 & 9 & 3.25 & 1 & 100.00 & 8 & 88.89 \\
\hline 1 & 1.43 & 4 & 1.42 & 1 & 100.00 & 3 & 75.00 & 1 & 1.54 & 13 & 4.69 & 1 & 100.00 & 9 & 69.23 \\
\hline 0 & 0 & 0 & 0 & 0 & 0 & 0 & 0 & 0 & 0 & 5 & 1.81 & 0 & 0 & 3 & 60.00 \\
\hline 0 & 0 & 0 & 0 & 0 & 0 & 0 & 0 & 10 & 15.38 & 35 & 12.63 & 7 & $70.00^{\mathrm{b}}$ & 34 & $97.14^{\mathrm{a}}$ \\
\hline 0 & 0 & 0 & 0 & 0 & 0 & 0 & 0 & 4 & 6.15 & 13 & 4.69 & 4 & 100.00 & 13 & 100.00 \\
\hline 0 & 0 & 0 & 0 & 0 & 0 & 0 & 0 & 1 & 1.54 & 13 & 4.69 & 0 & 0 & 8 & 61.54 \\
\hline 0 & 0 & 0 & 0 & 0 & 0 & 0 & 0 & 9 & 13.85 & 19 & 6.86 & 7 & 77.78 & 14 & 73.68 \\
\hline 5 & 7.14 & 7 & 2.48 & 0 & $0.00^{\mathrm{b}}$ & 5 & $71.43^{\mathrm{a}}$ & 0 & 0 & 3 & 1.08 & 0 & 0 & 0 & 0 \\
\hline 0 & 0 & 0 & 0 & 0 & 0 & 0 & 0 & 1 & 1.54 & 1 & 0.36 & 0 & 0 & 0 & 0 \\
\hline 0 & 0 & 0 & 0 & 0 & 0 & 0 & 0 & 7 & 10.77 & 24 & 8.66 & 5 & 71.43 & 19 & 79.17 \\
\hline 0 & 0 & 0 & 0 & 0 & 0 & 0 & 0 & 1 & 1.54 & 5 & 1.81 & 1 & 100.00 & 5 & 100.00 \\
\hline 0 & 0 & 0 & 0 & 0 & 0 & 0 & 0 & 1 & 1.54 & 5 & 1.81 & 0 & 0 & 0 & 0 \\
\hline 0 & 0 & 0 & 0 & 0 & 0 & 0 & 0 & 0 & 0 & 1 & 0.36 & 0 & 0 & 0 & 0 \\
\hline 0 & 0 & 1 & 0.35 & 0 & 0 & 1 & 100.00 & 4 & 6.15 & 14 & 5.05 & 4 & 100.00 & 9 & 64.29 \\
\hline 0 & 0 & 1 & 0.35 & 0 & 0 & 1 & 100.00 & 9 & $13.85^{\mathrm{a}}$ & 9 & $3.25^{\mathrm{b}}$ & 5 & 55.56 & 8 & 88.89 \\
\hline
\end{tabular}

DISEASES

$\mathrm{a}, \mathrm{b}$ : Differences between the rates with different letters in the same lines are significant $(\mathrm{P}<0,05)$.

Table 3. Causes of culling in Brown Swiss and Simmental cows before and after calving (\%)

BEFORE CALVING

AFTER CALVING

\begin{tabular}{|c|c|c|c|c|c|c|c|c|c|c|c|c|}
\hline \multirow[t]{2}{*}{ DISEASES } & \multicolumn{2}{|c|}{$\begin{array}{c}\text { Brown Swiss } \\
\text { (N:70) }\end{array}$} & \multicolumn{2}{|c|}{$\begin{array}{c}\text { Simmental } \\
(\mathrm{N}: 282)\end{array}$} & \multicolumn{2}{|c|}{$\begin{array}{l}\text { Overall } \\
(\mathrm{N}: 352)\end{array}$} & \multicolumn{2}{|c|}{$\begin{array}{c}\text { Brown Swiss } \\
\text { (N:65) }\end{array}$} & \multicolumn{2}{|c|}{$\begin{array}{c}\text { Simmental } \\
(\mathrm{N}: 277)\end{array}$} & \multicolumn{2}{|c|}{$\begin{array}{l}\text { Overall } \\
(\mathrm{N}: 342)\end{array}$} \\
\hline & $\mathbf{n}$ & $\%$ & $\mathbf{n}$ & $\%$ & $\mathbf{n}$ & $\%$ & $\mathbf{n}$ & $\%$ & $\mathbf{n}$ & $\%$ & $\mathbf{n}$ & $\%$ \\
\hline Diarrhea, constipation & 0 & 0 & 1 & 20.10 & 1 & 10.00 & 0 & 0 & 1 & 2.56 & 1 & 1.85 \\
\hline Pneumonia & 0 & 0 & 1 & 20.00 & 1 & 10.00 & 0 & 0 & 4 & 10.26 & 4 & 7.41 \\
\hline Uterine prolapse & 0 & 0 & 0 & 0 & 0 & 0 & 0 & 0 & 2 & 5.13 & 2 & 3.70 \\
\hline Metritis & 0 & 0 & 0 & 0 & 0 & 0 & 3 & 20.00 & 1 & 2.56 & 4 & 7.41 \\
\hline Retentio secondinarium & 0 & 0 & 0 & 0 & 0 & 0 & 0 & 0 & 0 & 0 & 0 & 0 \\
\hline Abscess adherence in uterus & 0 & 0 & 0 & 0 & 0 & 0 & 1 & 6.67 & 5 & 12.82 & 6 & 11.11 \\
\hline Ovarian cysts & 0 & 0 & 0 & 0 & 0 & 0 & 2 & 13.33 & 5 & 12.82 & 7 & 12.96 \\
\hline Idiopathic infertility & 5 & 100.00 & 2 & 40.00 & 7 & 70.00 & 0 & 0 & 3 & 7.69 & 3 & 5.56 \\
\hline Dystocia & 0 & 0 & 0 & 0 & 0 & 0 & 1 & 6.67 & 1 & 2.56 & 2 & 3.70 \\
\hline Mastitis & 0 & 0 & 0 & 0 & 0 & 0 & 2 & 13.33 & 5 & 12.82 & 7 & 12.96 \\
\hline Low milk yield & 0 & 0 & 0 & 0 & 0 & 0 & 1 & 6.67 & 5 & 12.82 & 6 & 11.11 \\
\hline Udder blindness & 0 & 0 & 0 & 0 & 0 & 0 & 0 & 0 & 1 & 2.56 & 1 & 1.85 \\
\hline Lameness & 0 & 0 & 0 & 0 & 0 & 0 & 0 & 0 & 5 & 12.82 & 5 & 9.26 \\
\hline Cachexia & 0 & 0 & 1 & 20.00 & 1 & 10.00 & 4 & $26.60^{\mathrm{a}}$ & 1 & $2.56^{\mathrm{b}}$ & 5 & 9.26 \\
\hline Idiopathic mortality & 0 & 0 & 0 & 0 & 0 & 0 & 1 & 6.67 & 0 & 0 & 1 & 1.85 \\
\hline GENERAL & 5 & $7.14^{a}$ & 5 & $1.77^{\mathrm{b}}$ & 10 & 2.84 & 15 & 23.08 & 39 & 14.08 & 54 & 15.79 \\
\hline
\end{tabular}

$\mathrm{a}, \mathrm{b}$ : Differences between the rates with different letters in the same lines are significant $(\mathrm{P}<0,05)$ 
Reasons such as the length of time required for cows' adaptation to machine milking after first calving, lack of experience of milking personal in the newlyestablished enterprise and failing to show enough sensitivity for milking hygiene might have increased mastitis rate.

Studies made in dairy farms with different breeds and different countries were reported that Retentio secondinarium incidence was 2,6-3\%; Metritis incidence was 2,9-32,6\%; Cystic Ovarian incidence was 9,6\%; Mastitis incidence was 1,3-6,5\%; Foot diseases incidence was $2-57,3 \%$ (Stanton et al. 2011, Sharifi et al. 2012, Stojic et al. 2013, Scköpke et al. 2013, Ansari-Lari et al. 2013, Hagiya et al. 2014, Koeck et al. 2014, Yin et al., 2014). The main reason for the difference between the reports and the cows after calving studied in this study might describe from the difference in researchers' disease definitions. Since the sub-clinic and clinic cases were assessed together in this study, it might cause having higher values than the sources calculating only clinic cases. In addition, the differences between studies in terms of breed, age, breeding location, breeding system (organic, conventional), season and disease appraisal period might be affected as the other reasons of differences in disease incidences (Seegers et al. 1998, Fetrow et al. 2006, Dinç A. 2016).

In this study, culling rate after calving was $15.79 \%$ (including voluntary culling and mortality), and the culling rate due to Genital problems among culled ones was $6.96 \%$. Those values were lower than the overall culling rates reported for different cattle breeds (Sharifi et al. 2012, Ansari-Lari et al. 2013, Ferguson et al. 2013, Stojic et al. 2013). Moreover, the fact that the most common reason for culling in this farm was genital problems such as metritis, cystic ovary and uterus complications etc. was consistent with reports (Seegers et al. 1998, Fetrow et al. 2006, Pinedo et al. 2010, Stojic et al. 2013). Digestive system problems caused more culling rates in Brown Swiss than Simmental cattle.

Difficulties experienced in the preparation and implementation of feed and ration protocols in the cattle breeding enterprise, which has started production for the first time, and also the lack of experience of the animal care workers, who worked in the farm and had a high turnover rate, might have increased the culling rates. The higher culling rates of Brown Swiss cows before and after calving shows the difference in the adaptation capacities of cattle breeds.

When study results are assessed together, the imported all cows had disease incidences of $9.38 \%$ before calving, and the treatment success rate was $70 \%$. Before calving, the most common diseases were digestive and Genital diseases. The success rate in treating diseases was higher for Simmental cows. The overall disease and culling incidences according to health parameters at the first production year of Simmental cows was equal or below the targeted values, which indicates that Simmental cows were higher adaptability than Brown Swiss cows in West Anatolia region of Turkey. These findings shows that Brown Swiss cows at the first production year are need to care under careful and attentive breeding and health program than Simmentals in this region.

\section{ACKNOWLEDGEMENT}

This study was arranged from a part of the first author's $P h D$ thesis. This work was supported by Scientific Research Projects Coordination Unit of Istanbul University (Project Number: 23141). Kücük Baykan Z., Örcan M., "Causes of culling and disease incidences at first production year of pregnant Brown Swiss and Simmental cows", 5th International VetIstanbul Group Congress \& 8th International Scientific Meeting Days of Veterinary Medicine-2018, Ohrid, MAKEDONYA, 23-27 Eylül 2018, pp.130-130. The research protocol of the current study was approved by the Ethic Committee of the Istanbul University (Approval number: 2012/31)

\section{REFERENCES}

Ansari-Lari M, Mohebbi-Fani M, Rowshan-Ghasrodashti A. Causes of culling in dairy cows and its relation to age at culling and interval from calving in Shiraz, southern Iran. Veterinary Research Forum. 2012; 3, 4: 233-237.

Broom DM. The effects of land transport on animal welfare. Rev. Sci. Tech. Off. Int. Epiz. 2005; 24, 2: 683-691.

Dinç A. Reproductive Performance Parameters of Dairy Cows. 4. Herd Health Symposium. 2016; 25-28 May 2016, Antalya, 111-128.

Ferguson JD, Skidmore A. Reproductive performance in a select sample of dairy herds. J. Dairy Sci. 2013; 96: 12691289.

Fetrow J, Nordlund KV, Norman HD. Culling: Nomenclature, definition and recommendations. J. Dairy Sci. 2006; 89: 1896-1905.

Hagiya K, Yamazaki T, Nagamine Y, Togashi K, Yamaguchi S, Gotoh Y, Kawahara T, Masuda Y, Suzuki M. Genetic correlations between production and disease traits during first lactation in Holstein cows. The Animal Consortium. 2014; 8, 2: 217-223.

Koeck A, Loker S, Miglior F, Kelton DF, Jamrozik J, Schenkel F. Genetic relationships of clinical mastitis, cystic ovaries, and lameness with milk yield and somatic cell score in first-lactation Canadian Holsteins. J. Dairy Sci. 2014; 97: 5806-5813.

Maher P, Good M, More SJ. Trends in cow numbers and culling rate in the Irish cattle population, 2003 to 2006. Irish Vet. J. 2008; 61, 7: 455-463.

Maizon DO, Oltenacu PA, Gröhn YT, Strawderman RL, Emanuelson U. Effects of diseases on reproductive performance in Swedish red and white dairy cattle. Preventive Vet. Med. 2004; 66: 113-126.

Municipality of Manisa (Date of access: 20.03.2017) (http://www.manisa.bel.tr/s23_manisa-cografyasi.aspx) 
Pinedo PJ, De Vries A, Webb DW. Dynamics of culling risk with disposal codes reported by dairy herd improvement dairy herds. J. Dairy Sci. 2010; 93: 2250-2261.

Schöpke K, Weidling S, Pijl R, Swalve HH. Relationships between bovine hoof disorders, body condition traits, and test-day yields. J. Dairy Sci. 2013; 96: 679-689.

Seegers H, Beauddeau F, Fourichon C, Bareille N. Reasons for culling in French Holstein cows. Preventive Vet. Med. 1998; 36: 257-271.

Sharifi H, Kostoulas P, Bahonar A, Bokaie S, Vodjgani M, Hangdoost AA, Karamouzian M, Foroushani AR, Leontides L. Effect of health disorders on the hazard of culling on the first or second lactation in Iranian dairy herds. Preventive Vet. Med. 2012; 109: 144-147.

SPSS. Statistical Package For The Social Sciences, Release 10.0. 1999, SPSS Inc. IL, Chicago, USA.

Stanton AL, Kelton DF, Leblanc SJ, Wormuth Leslie KE. The effect of respiratory disease and a preventative antibiotic treatment on growth, survival, age at first calving, and milk production of dairy cows. J. Dairy Sci. 2011; 95: 4950-4960.

Stojic P, Beskorovajni R, Pantelic V, Novakovic Z, Kovacevic S, Stanojevic D. Causes for culling first calving cows on farms with different levels of production. Biotechnology In Animal Husbandry. 2013; 29, 2: 259267.

Yin T, Bapst B, Von Borstel UU, Simianer H, König S. Genetic analyses of binary longitudinal health data in small low input dairy cattle herds using generalized linear mixed models. Livestock Sci. 2014; 162: 31-41. 